\title{
Intrathecal enzyme replacement therapy for CLN2 disease
}

\author{
Alfried Kohlschütter \\ University Medical Center Hamburg-Eppendorf, Hamburg, Germany \\ Prof. Dr. Alfried Kohlschütter \\ E-mail: kohlschuetter@uke.uni-hamburg.de \\ Department of Pediatrics \\ University Medical Center Hamburg-Eppendorf \\ Box 54, Martinistr. 52, 20246 Hamburg, Germany
}

Condensed from a lecture at the XIII International Raisa Gorbacheva Memorial Meeting in Saint Petersburg, 21 September 2019

Citation: Kohlschütter A. Intrathecal enzyme replacement therapy for CLN2 disease. Cell Ther Transplant 2019; 8(4): 29-32.

\section{Summary}

Neuronal ceroid-lipofuscinosis 2 (CLN2) is a genetic, rapidly progressive brain disorder of young humans. It leads to dementia, dramatic loss of all abilities and early death. It is caused by the deficiency of the lysosomal enzyme tripeptidyl peptidase 1 (TPP1) in the nervous system. This article is an overview of the development of replacing the deficient enzyme by repeated infusion of recombinant TPP1 in a brain ventricle, shown to be effective in halting the rapid progression of the disease.

\section{Keywords}

Neuronal ceroid-lipofuscinosis 2, tripeptidyl peptidase 1, deficiency, dementia, recombinant enzyme, local infusion, clinical effect.

\section{Introduction}

Dementia is an incurable loss of mental abilities. Dementia in elderly persons is a frequent condition and presents a large public health problem worldwide [1]. It has many different causes, among them primary genetic factors or the sequelae of other diseases such as vascular disorders. The pathogenesis of these forms of dementia is in general poorly understood, which is the major reason for the helpless attempts at developing therapies. Dementia in children - in contrast - is a rare phenomenon. Its causes are frequently well defined genetically, and its pathogenesis is sometimes well understood, which offers chances to develop a rational therapeutic approach.

The most frequent cause of dementia in young persons is a group of diseases called the Neuronal Ceroid-Lipofuscinoses (NCL). This group comprises more than a dozen diseases that are caused by mutations in different genes. All NCL have characteristic features in common: a variable clinical syndrome of dementia, epilepsy and retinopathy, as well as intracellular storage of an abnormal wax-like material called ceroid lipofuscin. The storage process causes degeneration and death of neuronal and retinal cells. NCL are presently classified according to the responsible mutated genes (CLN1, CLN2 etc.). Some of the gene mutations cause deficiencies of soluble lysosomal enzymes, others lead to dysfunction of lysosomal membrane proteins [2].

CLN2 disease, also called classical late-infantile NCL or Janský-Bielschowsky disease, typically strikes healthy-looking and normally developed 3-year-old toddlers. At this age, the disease manifests itself either strikingly with severe epilepsy, or more gradually with a slowing of further development. This is followed by dramatic loss of all mental and motor abilities and paralleled by severe brain atrophy. At the age of about 6 years, the patients are completely helpless and blind. Death usually occurs at the age of 10 to 15 years. Several cases with later manifestation and slower course of the disease have been described [3].

The disease is caused by a profound deficiency of the lysosomal enzyme tripeptidyl peptidase 1 (TPP1) in the brain. TPP1 is a protease, targeted to lysosomes via a mannose 6-phosphate receptor.

It cleaves tripeptides and is activated by clipping of a prosegment. The natural substrate and function of the enzyme are unknown, but it is clear that the deficiency of the enzyme causes storage of material and neurodegeneration. 


\section{Replacing a deficient brain protein}

Replacing the missing enzyme in the brain of CLN2 patients became an attractive concept, as many enzymes can now be fabricated, and because free lysosomal enzymes are frequently taken up easily by cells [4]. Human recombinant TPP1 was made by BioMarin. However, as the protein does not cross the blood-brain barrier, injection into the CSF space was used in pre-clinical experiments (Fig. 1). In TPP1-deficient mice this led to attenuation of the disease and extended survival. Important studies were done with a natural dog model of CLN2 disease. These TPP1-deficient dogs received the enzyme by infusion into the lumbar CSF space. Their functional improvement and prolonged survival were impressive compared with untreated dogs, which persuaded us to use the treatment for patients. Studies in monkeys demonstrated that the enzyme, when injected into CSF, reached wide areas of brain.

\section{CLN2 Disease - Replacing TPP1 in the Brain \\ Human recombinant TPP1 (BioMarin) \\ Does not cross the blod-brain barrier \\ Therefore intrathecal application \\ Preclinical studies

\begin{tabular}{|c|c|}
\hline Animal species & Results \\
\hline TPP1 ko Mouse & $\begin{array}{l}\text { - Disease attenuated } \\
\text { - Survival extension }\end{array}$ \\
\hline $\begin{array}{r}\text { TPP1-null Dachshund } \\
\text { Infusion into CSF }\end{array}$ & $\begin{array}{l}\text { - Functional improvement } \\
\text { - Survival extension }\end{array}$ \\
\hline Monkey & $\begin{array}{l}\text { - Dosing well tolerated } \\
\text { - Enzyme in many areas of brain }\end{array}$ \\
\hline
\end{tabular}

Figure 1. Preclinical studies with intrathecal application of TPP1 in various animal species and conclusions from results

In a clinical trial, we used the method illustrated in Fig. 2 for the application of TPP1. The enzyme (300 mg of the recombinant human TPP1, cerliponase A, Brineura ${ }^{\odot}$ ) is infused every 2 weeks through the skin into an implanted port, from where it is passed on over a thin tube to a lateral brain ventricle.

\section{CLN2 Disease - Method of Clinical Trial Replacing the Missing Enzyme (TPP1) in the brain \\ - Permanently in-dwelling subcutaneous port sitting in a skull burr-hole \\ - Catheter communicates between port and a lateral ventricle}

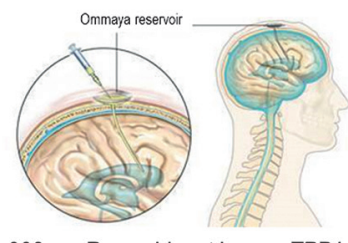

$300 \mathrm{mg}$ Recombinant human TPP1 (cerliponase A, Brineura $($, BioMarin) infused over $4 \mathrm{~h}$, every 2 weeks
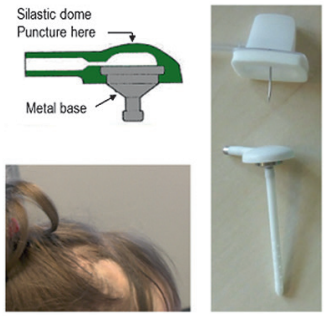

Measuring efficacy of a new treatment in a rare degenerative brain disease poses the serious problem of control patients. Placebo controls were unacceptable because of the aggressiveness of the procedure and the rarity of the condition. Our solution was to use a clinical scoring system we had specifically developed for CLN2 disease. Scoring of a large number of CLN2 patients over many years had resulted in a rather precise quantitative description of the disease course and its variability [5]. Fig. 3 shows that the clinical course of CLN2 disease is characterized (1) by a dramatic loss of motor and language abilities between the ages of three and six years and (2) by great uniformity in the majority of patients. On this basis it was decided that historical untreated patients could be used as controls.

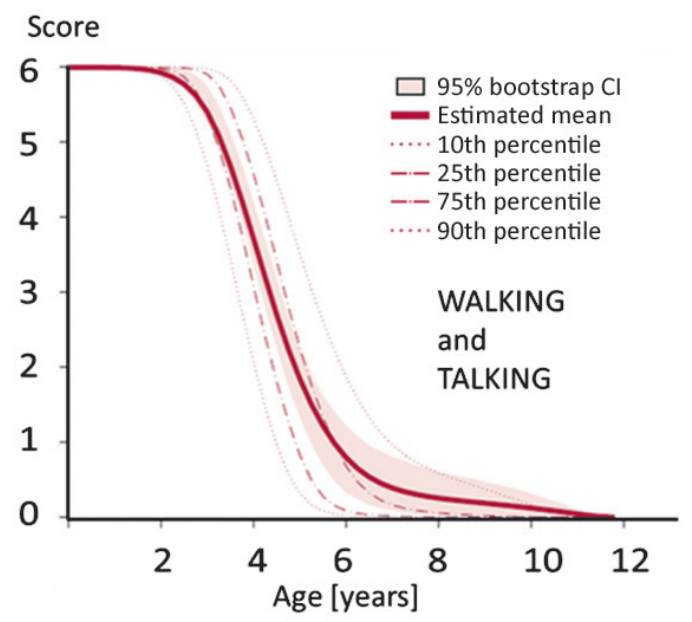

Figure 3. Results of clinical scoring of CLN2 patients from 0 to 12 years of age

Note: The score used here is a combined score for the ability of a child to walk and talk. Normal walking and talking abilities result in 3 points for each ability ( 6 points on this scale). Loss of abilities is scored with 2 points for a minor disturbance, 1 point for a major disturbance, and 0 points for total loss of the respective function. There is a dramatic loss of abilities between 3 and 6 years of age. The course of the disease is very uniform. (Redrawn from [5]).

\section{Clinical trial}

A clinical trial with intrathecal TPP1 replacement therapy was performed with international cooperation and Angela Schulz as principal investigator as shown in Fig. 4. This was an open-label phase I/II dose escalation study performed 2013-2016. An extension study is presently ongoing.

Enrolled were twenty-four patients. Of them, 23 completed the study. Efficacy was measured against matched historical controls. Adverse events were relatively minor: We had some infections that could be managed easily, and there were some failures of the intraventricular device. None of the adverse events led to discontinuation of treatment [6].

Results of the trial are illustrated by Fig. 5, which shows the striking capacity of the treatment to halt the expected dramatic loss of motor and language abilities. 


\section{CLN2 Disease - Clinical Trial}

Study of Intraventricular Cerliponase Alfa for CLN2 Disease N EnglJ Med 2018;378:1898-907

Angela Schulz, M.D., Temitayo Ajayi, M.D., Nicola Specchio, M.D., Ph.D., Emily de Los Reyes, M.D., Paul Gissen, M.B., Ch.B., Ph.D., Douglas Ballon, Ph.D., Jonathan P. Dyke, Ph.D., Heather Cahan, M.D., Peter Slasor, Sc.D. David Jacoby, M.D., Ph.D., and Alfried Kohlschütter, M.D. for the CLN2 Study Group"

Department of Pediatrics,University Medical Center, Hamburg, Germany Nationwide Children's Hospital and Ohio State University. $\quad$ Columbus, Ohi UCL Great Ormond Street Institute for Child Health, London, U.K. Depts. of Radiology and Genetic Medicine, Weill Cornell Medical College, New York, N.Y.

Figure 4. Investigators and participant institutions at the clinical trial with enzyme replacement therapy for CLN2 disease

\section{CLN2 Disease - Results of Clinical Trial Intraventricular enzyme replacement}

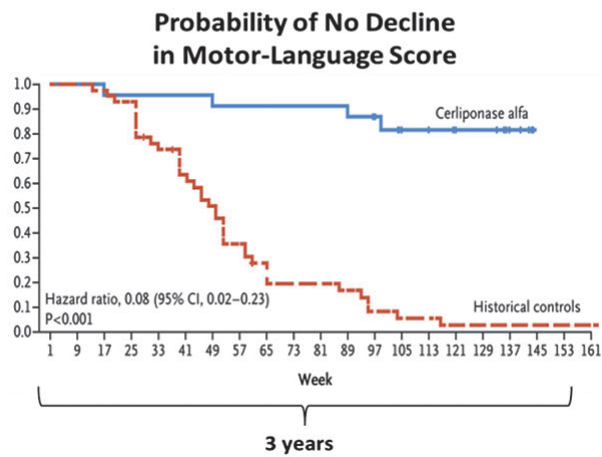

Figure 5. Risk of losing motor and language abilities in 23 children with CLN2 disease treated with intraventricular TPP1 (cerliponase $A$, Brineura ${ }^{\odot}$ ) over a three-year period (blue line), compared to matched untreated historical controls (red line). Probabilities of no functional decline were calculated on the basis of motor-language scoring (see figure 3). From [6]

\section{Summary and conclusions}

Effective treatment of CLN2 disease, a rare childhood dementia, has become possible through a combination of favorable factors:

(1) The pathogenetic mechanism was known (lack of a lysosomal enzyme in brain).

(2) The deficient protein could be synthesized.

(3) For preclinical studies, a large experimental animal (natural dog model) was available.

(4) The blood-brain barrier was overcome by intra-ventricular infusion.

(5) The clinical course of the disease and its variability were sufficiently known. Historical controls could therefore be used and placebo controls avoided.

Many questions remain. We have no long-term results of this treatment. Will life-long treatment be necessary? What will be the further development of the treated patients? Are we creating a chronic disease from a dramatically cruel, relatively acute condition? An additional therapeutic approach to the retinopathy will have to be developed. Will new treatments, such as gene therapy, be safe and more effective than enzyme replacement [7]? At any rate, the results of this trial with replacement of a deficient brain protein has pushed open a door. Some principles underlying this study of a rare childhood disease may be applicable to other, much more frequent forms of dementia.

\section{Conflict of interests}

None declared.

\section{References}

1. World Health Organization. Dementia: a public health priority. 2012, Geneva: Publications of the World Health Organization.

2. Nita DA, Mole SE, Minassian BA. Neuronal ceroid lipofuscinoses. Epileptic Disord, 2016; 18(S2): 73-88.

3. Kohlschütter A, Schulz A. CLN2 Disease (Classic Late Infantile Neuronal Ceroid Lipofuscinosis). Pediatric Endocrinology (Diabetes, Nutrition, Metabolism) Reviews, 2016; 13(Suppl 1): 682-688.

4. Neufeld EF. Enzyme replacement therapy - a brief history, in Fabry Disease: Perspectives from 5 Years of FOS, A. Mehta, M. Beck, and G. Sunder-Plassmann, Editors. 2006: Oxford.

5. Nickel M., Simonati A, Jacoby D, Lezius S, Kilian D, Van de Graaf B, Pagovich OE, Kosofsky B, Yohay K, Downs M, Slasor P, Ajayi T, Crystal RG, Kohlschutter A, Sondhi D, Schulz A. Disease characteristics and progression in patients with late-infantile neuronal ceroid lipofuscinosis type 2 (CLN2) disease: an observational cohort study. Lancet Child Adolesc Health, 2018; 2(8): 582-590.

6. Schulz A, Ajayi T, Specchio N, de Los Reyes E, Gissen P, Ballon D, Dyke JP, Cahan H, Slasor P, Jacoby D, Kohlschutter A, and CLN Study Group. Study of Intraventricular Cerliponase Alfa for CLN2 Disease. N Engl J Med, 2018; 378(20): 898-1907.

7. Kohlschütter A, Schulz A, Bartsch U, Storch S. Current and Emerging Treatment Strategies for Neuronal Ceroid Lipofuscinoses. CNS Drugs, 2019; 33(4): 315-325. 


\section{Интратекальная заместительная энзимотерапия нейронального цероидного липофусциноза}

\section{Альфред Кольшюттер}

Университетский медицинский центр Гамбург-Эппендорф, Гамбург, Германи

\section{Резюме}

Нейрональный цероидный липофусциноз (CLN2) является наследственным, быстро прогрессирующим заболеванием раннего возраста, ведущим к деменции, резкой утрате всех навыков и ранней гибели пациента. Оно вызывается дефицитом лизосомного фермента трипептидил-пептидазы 1 (ТPP1) в нервной системе. Настоящая статья является обзором разработок по замещению дефектного энзима посредством повторных инфузий рекомбинантного TPP1 в желудочки головного мозга. Показана эффективность метода в плане сдерживания быстрой прогрессии заболевания.

\section{Ключевые слова}

Нейрональный цероидный липофусциноз 2, трипептидил-пептидаза 1 , дефицит, деменция, рекомбинантный энзим, локальная инфузия, клинический эффект. 